\title{
Fatty acids profile of pulp and nuts of brazilian fruits
}

\author{
Perfil de ácidos graxos de polpa e castanhas de frutas brasileiras
}

\section{Paulo Afonso da COSTA ${ }^{1}$, Cristiano Augusto BALLUS ${ }^{1}$, José TEIXEIRA FILHO ${ }^{2}$, Helena Teixeira GODOY ${ }^{1 *}$}

\begin{abstract}
Fruits and nuts from the North and Northeast regions of Brazil were collected to determine the fatty acid profile of their oils. The species studied were Brazil (Bertholletia excelsa H.B.K.), Mucajá (Couma rigida M.), Inajá (Maximiliana maripa D.), Jenipapo (Genipa Americana L.), and Buriti (Mauritia flexuosa L.) nuts. Fatty acid methyl esters were analyzed by gas chromatography with flame ionization detection (GCFID). Brazil nut major fatty acid was 18:3n-3 ( $\alpha$-linolenic acid), and Buriti nut had approximately 23 times more 18:3n-3 than the pulp. Mucajá nut presented high content of 12:0 (lauric acid) and 16:0 (palmitic acid), and Mucajá pulp showed significant levels of 18:2n-6 (linoleic acid). Considering the PUFA (polyunsaturated fatty acid) sum values, almost all fruits and nuts analyzed presented very high levels of these compounds. Regarding n-6/n-3 ratio, only Brazil Nut, Buriti Nut, Inajá pulp, and Jenipapo pulp corresponded to the desired profile. These Brazilian fruits and nuts could be of potential interest due to their high nutritive value and lipid content.

Keywords: Bertholletia excelsa H.B.K.; Couma rigida M.; Maximiliana maripa D.; Genipa Americana L.; Mauritia flexuosa L.; Fatty acids; GC-FID.
\end{abstract}

\section{Resumo}

Frutas e castanhas das regiões Norte e Nordeste do Brasil foram coletadas para determinação da composição em ácidos graxos do óleo da polpa e da castanha. As espécies estudadas foram castanha-do-pará (Bertholletia excelsa H.B.K.), mucajá (Coumarigida M.), inajá (Maximilianamaripa D.), jenipapo (Genipa Americana L.) e buriti (Mauritia flexuosa L.). Os ésteres metílicos de ácidos graxos foram analisados por cromatografia gasosa com detector por ionização em chama (GC-FID). O ácido graxo majoritário da castanha-do-pará foi o 18:3n-3 (ácido a-linolênico). A castanha do buriti apresentou aproximadamente 23 vezes mais 18:3n-3 do que a polpa. A castanha do mucajá apresentou elevados teores de 12:0 (ácido láurico) e 16:0 (ácido palmítico), enquanto a polpa do mucajá mostrou níveis significativos de 18:2n-6 (ácido linoleico). Considerando o somatório de ácidos graxos poli-insaturados (PUFA), quase todas as frutas e castanhas analisadas apresentaram níveis bastante altos destes compostos. No que se refere à razão n-6/n-3, apenas a castanha-do-pará, a castanha de buriti, a polpa de inajá e a polpa de jenipapo corresponderam ao perfil desejado. Estas frutas e castanhas brasileiras podem ser de potencial interesse devido ao seu elevado valor nutritivo e teor de lipídios.

Palavras-chave: Bertholletia excelsa H.B.K.; Couma rigida M.; Maximiliana maripa D.; Genipa Americana L.; Mauritia flexuosa L.; ácidos graxos; GC-FID.

\section{Introduction}

Over the last few years, several Brazilian vegetable oils from native fruits and nuts have been studied. To make sure that they are suitable for commercial use, it is very important to investigate their chemical and physical properties (ESCRICHE et al., 1999; BEREAU; BENJELLOUN-MLAYAH; DELMAS, 2001; BEREAU et al., 2003; ALBUQUERQUE et al., 2005; RYAN et al., 2006; CHUNHIENG et al., 2008).

Fruits and nuts may be considered as important components of a healthy diet. In general, they are nutrient-dense foods and provide protein, fat (mostly unsaturated fatty acids), dietary fiber, and many bioactive constituents such as vitamins, minerals, antioxidants, and other phytochemicals. Given such variety of bioactive compounds, extensive research has focused on potential healthy effects of higher nut and seed consumption on the development of heart disease and prostate cancer (JENAB et al., 2004; SERINI et al., 2009).
The major constituents of oils are their fatty acids, which may include saturated fatty acids (SFA), monounsaturated fatty acids (MUFA), and polyunsaturated fatty acids (PUFA) that contribute to human physiology in different ways (MEHMOOD et al., 2008).

Dietary factors are associated with increasing levels of cardiovascular disease, certain types of cancers, stroke, obesity, non-insulin dependent diabetes mellitus, and atherosclerosis (KHOKHAR et al., 2009).

Extensive research has shown that PUFAs are indispensable for the proper functioning of the brain, the eyes, and the entire nervous system. PUFAs are often classified into two families, $\mathrm{n}-3$ and n-6, according to double bond positions. In spite of the important biological functions of both n- 3 and n- 6 groups, humans lack the enzymes required to form double bonds beyond

Received 30/3/2010

Accepted 9/7/2010 (004768)

${ }^{1}$ Department of Food Science, Faculty of Food Engineering, University of Campinas - UNICAMP, CP 6121, CEP 13083-862, Campinas, SP, Brazil, e-mail: helena@fea.unicamp.br

${ }^{2}$ Department of Water and Soil, Faculty of Agricultural Engineering, University of Campinas - UNICAMP, CP 6011, CEP 13083-970, Campinas, SP, Brazil

* Corresponding author 
the $\Delta 9$ position. To overcome this limitation, the primary PUFAs precursors, linoleic acid (LA, 18:2n-6) and $\alpha$-linolenic acid (ALA, 18:3n-3), also called essential fatty acids (EFAs), must be obtained from a diet (TRUKSA; VRINTEN; QIU, 2009).

Since saturated fatty acids increase the risks of cardiovascular diseases, cancer and autoimmune disorders, oils are of more nutritional value if they have proportionally more unsaturated than saturated fatty acids (MEHMOOD et al., 2008).

The determination of fatty acids is a routine method in food chemistry and food control. The lipid phase is extracted with organic solvents, and the fatty acid profile is determined after transesterification into fatty acid methyl esters (FAMEs), followed by gas chromatography-flame ionization detector (GC-FID) analysis. GC-FID is the method of choice for the determination of relative contributions of individual fatty acids to the fatty acid pattern due to the relative constant response factors irrespective of the chain length and number of double bonds (THOMPSON, 1996; TORRES; TRUGO; TRUGO, 2002; THURNHOFER; VETTER, 2006; VENKATACHALAM; SATHE, 2006; FARKAS et al., 2008).

Food composition databases that are comprehensive and representative of available foods provide detailed information on nutrients and dietary factors in foods (KHOKHAR et al., 2009). Thus, the aim of this study was to determine the fatty acids profile of different fruits and nuts from the North and Northeast regions of Brazil, so as to provide reliable data on the nutritional composition of some Brazilian native foods.

\section{Materials and methods}

\subsection{Chemicals}

Hexane, acetone, methanol, and n-heptane (all of HPLCgrade) were purchased from J. T. Baker (USA). Ethanol (99.8\%), $\mathrm{NaOH}, \mathrm{NH}_{4} \mathrm{Cl}$, and $\mathrm{Na}_{2} \mathrm{SO}_{4}$ were of analytical grade.

\subsection{Samples}

This work was carried out using fruits and nuts obtained from the North and Northeast regions of Brazil, which were harvested from the native trees of these regions. All samples were collected by Embrapa-PA, packed, frozen, and sent to the Food Analysis Laboratory of Unicamp by airplane. Three different batches were analyzed; each of them representing an annual harvest (2004, 2005 and 2006). Approximately $0.5 \mathrm{~kg}$ of fruits and nuts was received from each harvest. Table 1 shows the fruits and nuts assayed in this study.

\subsection{Sample preparation}

The pulp of the total batch (harvest) was homogenized in a food processor and divided into portions for subsequent analysis. Each portion was distributed into plastic bags. The air was removed from the plastic bags, which were then sealed and stored under refrigeration $\left(2{ }^{\circ} \mathrm{C}\right)$ until analysis. The nuts were ground using a Kinematics A10 homogenizator (model CH6014).

\subsection{Total lipids extraction}

The extraction of the oil contained in these fruits (pulp) and nuts was done by using the method described by Sadler, Davis and Dezman (1990), so as to avoid the use of organochlorinated solvents in the sample treatment. The oil was obtained by solvent evaporation in a rotary evaporator (Buchi) at $60{ }^{\circ} \mathrm{C}$ under vacuum. The oily fraction resulting from the cold extraction was transferred to a test tube with cap, which was then kept in a freezer at $-18^{\circ} \mathrm{C}$ until analysis.

\subsection{Fatty acids determination}

About $0.25 \mathrm{~g}$ of oil sample was weighed in a flask. Next, $5.0 \mathrm{~mL}$ of a methanolic solution of $\mathrm{NaOH} 0.5$ mol. $\mathrm{L}^{-1}$ was added, and the mixture was heated for 20 minutes, resulting in the oil saponification. $10.0 \mathrm{~mL}$ of a metilation solution $(2.0 \mathrm{~g}$ of $\mathrm{NH}_{4} \mathrm{Cl}, 60.0 \mathrm{~mL}$ of methanol, and $3.0 \mathrm{~mL}^{\circ} \mathrm{H}_{2} \mathrm{SO}_{4}$ ) were then transferred to the flask, to convert free fatty acids into methyl esters. Subsequently, $5.0 \mathrm{~mL}$ of $\mathrm{n}$-heptane were added to the flask causing methyl esters partitioning from the aqueous phase to the upper organic phase. This organic phase was collected and transferred to a test tube containing $\mathrm{Na}_{2} \mathrm{SO}_{4}$. The $\mathrm{n}$-heptane phase containing methyl esters was kept in $2.0 \mathrm{~mL}$-flasks with caps, and $0.1 \mathrm{~mL}$ of this solution was injected in the gas chromatograph. The samples were analyzed in duplicate.

\subsection{Methyl esters gas chromatography}

Fatty acids methyl esters were determined by gas chromatography using a GC14A (Shimadzu) gas chromatograph equipped with a flame ionization detector (FID), a split/splitless capillary inlet system, and a CP-Sil 88 WCOT fused silica capillary column (Varian) with dimensions of $50 \mathrm{~m} \times 0.25 \mathrm{~mm}$ id $\mathrm{x} 0.20 \mu \mathrm{m}$ film thickness. The operation parameters used were: injector temperature: $210{ }^{\circ} \mathrm{C}$; detector temperature: $230{ }^{\circ} \mathrm{C}$; column temperature starting at $150^{\circ} \mathrm{C}$ (holding for 0 minutes), increasing $0.4^{\circ} \mathrm{C} /$ minutes to $160^{\circ} \mathrm{C}$ (holding for 2 minutes), and then increasing $5^{\circ} \mathrm{C} /$ minutes to $200^{\circ} \mathrm{C}$ (holding for 10 minutes) - total analysis time: 45 minutes; carrier gas: hydrogen $\left(\mathrm{H}_{2}\right)$ at a linear velocity of $30 \mathrm{~cm} \cdot \mathrm{s}^{-1}$; and split ratio of 1:60. This method was adapted from ISO 15304:2002(E) (2002). Retention time and peak areas were registered by means of Chromatopack 3.1 software (Shimadzu).

\subsection{Fatty acid identification}

Fatty acids methyl esters were identified by comparing the retention time of the samples and appropriate fatty acids methyl esters standards, purchased from Merck (Darmstadt, Germany).

Table 1. Fruits and nuts analyzed in this study

\begin{tabular}{llccl}
\hline $\begin{array}{c}\text { Fruit or } \\
\text { nut }\end{array}$ & \multicolumn{1}{c}{$\begin{array}{c}\text { Scientific } \\
\text { name }\end{array}$} & $\begin{array}{c}2005 \\
\text { Harvest }\end{array}$ & $\begin{array}{c}2006 \\
\text { Harvest }\end{array}$ & $\begin{array}{c}\text { Analyzed part } \\
\text { of the fruit }\end{array}$ \\
\hline Brazil nut & Bertholletia excelsa H.B.K & $\mathrm{x}$ & $\mathrm{x}$ & Nut \\
Mucajá & Couma rigida M. & $\mathrm{x}$ & $\mathrm{x}$ & Pulp and nut \\
Inajá & Maximiliana maripa D. & $\mathrm{x}$ & $\mathrm{x}$ & Pulp \\
Jenipapo & Genipa americana L. & $\mathrm{x}$ & $\mathrm{x}$ & Pulp \\
Buriti & Mauritia flexuosa L. & $\mathrm{x}$ & $\mathrm{x}$ & Pulp and nut \\
\hline
\end{tabular}


Fatty acids profile of brazilian fruits

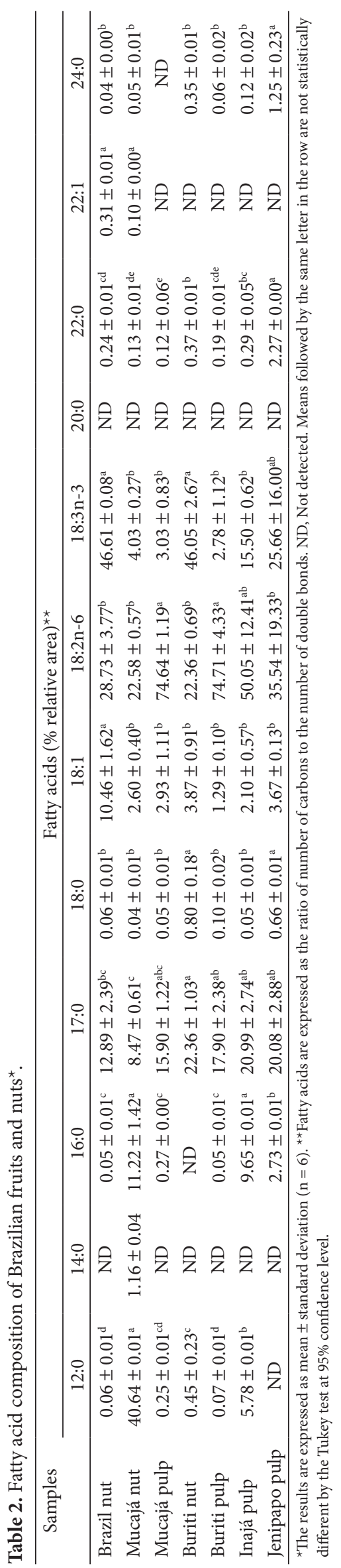


Each fatty acid was expressed in percentage of relative area, obtained by area normalization (fatty acid peak area relative to chromatogram total area).

\subsection{Statistical analysis}

The fatty acid composition of the samples was submitted to Analysis of Variance (ANOVA), and the means were compared for statistically significant differences by the Tukey test $(\mathrm{p}<0.05)$ using Statistica 7.0 software (Statsoft, USA).

\section{Results and discussion}

As can be seen in Table 2, Brazil Nut major fatty acids were 18:3n-3 ( $\alpha$-linolenic acid) and 18:1 (oleic acid). However, other studies showed a different fatty acid profile, in which the main fatty acid was $18: 1$ in a range of $28.7-39.3 \%$ and $18: 2$ between 36.1-42.8\% (RYAN et al., 2006; CHUNHIENG et al., 2008; VENKATACHALAM; SATHE, 2006).

Buriti pulp exhibited a high level of 18:2 (linoleic acid, LA), while Buriti nut had approximately 23 times more 18:3 than the pulp. Both linolenic acid and LA are essential fatty acids since linolenic acid is precursor of eicosapentaenoic acid (EPA) and LA is precursor of arachidonic acid (which are precursors of prostaglandins, thromboxanes, and leukotrienes in humans) (TAPIERO et al., 2002).

Analyzing the fatty acid profile of the oil extracted from Buriti pulp, Albuquerque et al. (2005) found that the oil composition presented high 18:1 (73.3-78.73\%) and low 18:2 (2.4-3.93\%) contents, which is in accordance with the results obtained in previous studies (ESCRICHE et al., 1999).

Considering Mucajá nut, a high content of saturated fatty acids 12:0 (lauric acid) and 16:0 (palmitic acid) was found. Some studies demonstrated that lauric and palmitic acids could increase cholesterol levels if consumed in excess quantities, but more studies are needed on this subject (DUBOIS et al., 2007). On the other hand, Mucajá pulp showed significant levels of 18:2. Therefore, Mucajá pulp and nut presented contradictory fatty acids profiles. Data on fatty acid composition of Mucajá pulp and nut oils were not found in the literature.

Inajá pulp presented high content of 18:2; however, other authors (BEREAU; BENJELLOUN-MLAYAH; DELMAS, 2001) found significant content of 18:1 (41.5\%), 14:0 (18.7\%), and 16:0 (18.6\%).

The quantitative differences verified between the literature data and the results obtained in this study can be explained by several reasons such as edafoclimatic conditions, genetic variation, cultivar, variation between years, degree of ripening when harvested, and even storage conditions of samples before arrival at the laboratory (MSAADA et al., 2009; WANNES; MHAMDI; MARZOUK, 2009).

Table 3 summarizes the fatty acid profile as a sum of different classes encountered in the fruits and nuts.

From the samples analyzed, Mucajá nut showed the highest SFA sum, while Brazil nut had the lowest content of SFA. Regarding MUFA total content, Brazil nut had the highest
Table 3. Total contents (\%) of SFA, MUFA, PUFA, and n-6/n-3 ratio of Brazilian fruits and nuts*.

\begin{tabular}{|c|c|c|c|c|}
\hline Fruits & $\sum$ SFA & $\sum$ MUFA & $\sum$ PUFA & $n-6 / n-3$ \\
\hline Brazil nut & $13.16 \pm 2.23^{b}$ & $10.61 \pm 1.84^{\mathrm{a}}$ & $75.34 \pm 3.85^{\mathrm{a}}$ & $0.62 \pm 0.08^{c}$ \\
\hline Mucajá nut & $61.68 \pm 2.00^{\mathrm{a}}$ & $2.70 \pm 0.40^{\mathrm{b}}$ & $26.61 \pm 0.84^{\mathrm{b}}$ & $5.61 \pm 0.23^{\mathrm{bc}}$ \\
\hline Mucajá pulp & $16.59 \pm 1.27^{\mathrm{b}}$ & $2.93 \pm 1.11^{\mathrm{b}}$ & $77.67 \pm 2.02^{\mathrm{a}}$ & $25.58 \pm 6.60^{\mathrm{ab}}$ \\
\hline Buriti nut & $23.96 \pm 1.94^{\mathrm{b}}$ & $3.87 \pm 0.91^{\mathrm{b}}$ & $68.41 \pm 1.99^{\mathrm{a}}$ & $0.49 \pm 0.04^{c}$ \\
\hline Buriti pulp & $18.29 \pm 2.60^{\mathrm{b}}$ & $1.29 \pm 0.10^{\mathrm{b}}$ & $77.49 \pm 3.20^{\mathrm{a}}$ & $29.67 \pm 13.58^{\mathrm{a}}$ \\
\hline Inajá pulp & $29.15 \pm 13.58^{b}$ & $2.10 \pm 0.57^{\mathrm{b}}$ & $65.54 \pm 11.79^{a}$ & $3.25 \pm 0.93^{\mathrm{bc}}$ \\
\hline Jenipapo pulp & $25.63 \pm 0.74^{\mathrm{b}}$ & $3.67 \pm 0.13^{\mathrm{b}}$ & $61.19 \pm 3.32^{\mathrm{a}}$ & $2.01 \pm 2.00^{c}$ \\
\hline
\end{tabular}

percentage. Considering PUFA sum, almost all fruits and nuts analyzed presented very high levels of these compounds, except for Mucajá nut that, in contrast, showed elevated contents of SFA.

According to the literature (GARG et al., 2006), it is recommended that the ratio of $n-6$ to $n-3$ should not exceed 4 to 1 in order to optimize bioavailability, metabolism, and incorporation into membrane phospholipids. In this case, only Brazil nut, Buriti nut, Inajá pulp and Jenipapo pulp corresponded to the desired profile of fatty acids regarding n-6/n-3 ratio (Table 3 ).

\section{Conclusion}

The fruits and nuts of the North and Northeast regions of Brazil studied in this research are of potential interest due to their high nutritive value and lipid content. They are alternative foods for the population who live in these regions, but they could be also a source of high-quality vegetable oils that could be sold contributing considerably to tropical forests conservation. The cultivation of these plants, which has been traditionally carried out by the natives since ancient times, should be encouraged.

\section{Acknowledgements}

The authors would like to thank Unilever Foods Brazil Ltda (Valinhos-SP) and Marcus, Embrapa-PA researcher.

\section{References}

ALBUQUERQUE, M. L. S. et al. Characterization of Buriti (Mauritia flexuosa L.) Oil by Absorption and Emission Spectroscopies. Journal of the Brazilian Chemical Society, v. 16, p. 1113-1117, 2005. http:// dx.doi.org/10.1590/S0103-50532005000700004

BEREAU, D. et al. FA and Unsaponifiable Composition of Five Amazonian Palm Kernel Oils. Journal of the American Oil Chemists' Society, v. 80, p. 49-53, 2003.

BEREAU, D.; BENJELLOUN-MLAYAH, B.; DELMAS, M. Maximiliana maripa Drude Mesocarp and Kernel Oils: Fatty Acid and Total Tocopherol Compositions. Journal of the American Oil Chemists' Society, v. 78, p. 213-214, 2001

CHUNHIENG, T. et al. Detailed Study of Brazil Nut (Bertholletia excelsa) Oil Micro-Compounds: Phospholipids, Tocopherols and 
Sterols. Journal of the Brazilian Chemical Society, v. 19, p. 13741380, 2008. http://dx.doi.org/10.1590/S0103-50532008000700021

DUBOIS, V. et al. Fatty acid profiles of 80 vegetable oils with regard to their nutritional potential. European Journal of Lipid Science and Technology, v. 109, p. 710-732, 2007. http://dx.doi.org/10.1002/ ejlt.200700040

ESCRICHE, I. et al. Composition and nutritive value of Amazonian palm fruits. Food Nutrition Bulletin, v. 20, p. 361-365, 1999.

FARKAS, O. et al. Prediction of retention indices for identification of fatty acid methyl esters. Journal of Chromatography A, v. 11981199, p. 188-195, 2008. PMid:18533170. http://dx.doi.org/10.1016/j. chroma.2008.05.019

GARG, M. L. et al. Means of Delivering Recommended Levels of Long Chain n-3 Polyunsaturated Fatty Acids in Human Diets. Journal of Food Science, v. 71, p. R66-R71, 2006.

INTERNATIONAL ORGANIZATION FOR STANDARDIZATION. ISO:15304:2002(E): Animal and vegetable fats and oils Determination of the content of trans fatty acid isomers of vegetable fats and oils - Gas chromatographic method. ISO, 2002. p. 1-20

JENAB, M. et al. Association of Nut and Seed Intake with Colorectal Cancer Risk in the European Prospective Investigation into Cancer and Nutrition. Cancer Epidemiology, Biomarkers \& Prevention, v. 13, p. 1595-1603, 2004.

KHOKHAR, S. et al. Harmonised procedures for producing new data on the nutritional composition of ethnic foods. Food Chemistry, v. 113, p. 816-824, 2009. http://dx.doi.org/10.1016/j. foodchem.2008.06.046

MEHMOOD, S. et al. Fatty acid composition of seed oil of different Sorghum bicolor varieties. Food Chemistry, v. 109, p. 855-859, 2008. http://dx.doi.org/10.1016/j.foodchem.2008.01.014

MSAADA, $K$. et al. Changes in fatty acid composition of coriander (Coriandrum sativum L.) fruit during maturation. Industrial Crops and Products, v. 29, p. 269-274, 2009. http://dx.doi.org/10.1016/j. indcrop.2008.05.011

RYAN, E. et al. Fatty acid profile, tocopherol, squalene and phytosterol content of brazil, pecan, pine, pistachio and cashew nuts. International Journal of Food Science and Nutrition, v. 57, p. 219-228, 2006.
PMid:17127473. http://dx.doi.org/10.1080/09637480600768077 SADLER, G.; DAVIS, J.; DEZMAN, D. Rapid Extraction of Lycopene and $\beta$-Carotene from Reconstituted Tomato Paste and Pink Grapefruit Homogenates. Journal of Food Science, v. 55, p. 14601461, 1990. http://dx.doi.org/10.1111/j.1365-2621.1990.tb03958.x

SERINI, S. et al. Dietary polyunsaturated fatty acids as inducers of apoptosis: implications for cancer. Apoptosis, v. 14, p. 135152, 2009. PMid:19130233. http://dx.doi.org/10.1007/s10495008-0298-2

TAPIERO, H. et al. Polyunsaturated fatty acids (PUFA) and eicosanoids in human health and pathologies. Biomedicine \& Pharmacotherapy, v. 56, p. 215-222, 2002. http://dx.doi. org/10.1016/S0753-3322(02)00193-2

THOMPSON, R. H. Simplifying Fatty Acid Analyses in Multicomponent Foods with a Standard Set of Isothermal GLC Conditions Coupled with ECL Determinations. Journal of Chromatographic Science, v. 34, p. 495-504, 1996.

THURNHOFER, S.; VETTER, W. Application of Ethyl Esters and $d_{3-}$ Methyl Esters as Internal Standards for the Gas Chromatographic Quantification of Transesterified Fatty Acid Methyl Esters in Food. Journal of Agricultural and Food Chemistry, v. 54, p. 32093214, 2006. PMid:16637674. http://dx.doi.org/10.1021/jf053022j TORRES, A. G.; TRUGO, N. M.; TRUGO, L. C. Mathematical Method for the Prediction of Retention Times of Fatty Acid Methyl Esters in Temperature-Programmed Capillary Gas Chromatography. Journal of Agricultural and Food Chemistry, v. 50, p. 41564163, 2002. PMid:12105939. http://dx.doi.org/10.1021/jf011259j

TRUKSA, M.; VRINTEN, P.; QIU, X. Metabolic engineering of plants for polyunsaturated fatty acid production. Molecular Breeding, v. 23, p. 1-11, 2009. http://dx.doi.org/10.1007/s11032-008-9218-y

VENKATACHALAM, M.; SATHE, S. K. Chemical Composition of Selected Edible Nut Seeds. Journal of Agricultural and Food Chemistry, v. 54, p. 4705-4714, 2006. PMid:16787018. http://dx.doi. org/10.1021/jf0606959

WANNES, W. A.; MHAMDI, B.; MARZOUK, B. Variations in essential oil and fatty acid composition during Myrtus communis var. italica fruit maturation. Food Chemistry, v. 112, p. 621-626, 2009. http:// dx.doi.org/10.1016/j.foodchem.2008.06.018 